5-1992

\title{
Keeping College Affordable: A Proposal From Two Economists
}

University of Pennsylvania

Follow this and additional works at: https://repository.upenn.edu/cpre_policybriefs

Part of the Education Economics Commons, Education Policy Commons, Higher Education Commons, and the Higher Education Administration Commons

\section{Recommended Citation}

University of Pennsylvania. (1992). Keeping College Affordable: A Proposal From Two Economists. CPRE Policy Briefs.

Retrieved from https://repository.upenn.edu/cpre_policybriefs/65

This document was authored by the Consortium for Policy Research in Education but no individual authors were identified.

View on the CPRE website.

This paper is posted at ScholarlyCommons. https://repository.upenn.edu/cpre_policybriefs/65

For more information, please contact repository@pobox.upenn.edu. 


\title{
Keeping College Affordable: A Proposal From Two Economists
}

\author{
Abstract \\ In order to broaden discussion about higher education finance, this policy brief outlines a proposal for a \\ major change in federal financial aid, state tuition, and state financial aid policies. The proposal is drawn \\ from the book Keeping College Affordable: Government and Educational Opportunity by Michael S. \\ McPherson and Morton Owen Schapiro. \\ Disciplines \\ Education Economics | Education Policy | Higher Education | Higher Education Administration

\section{Comments} \\ This document was authored by the Consortium for Policy Research in Education but no individual \\ authors were identified. \\ View on the CPRE website.
}




\section{Keeping College Affordable A Proposal from Two Economists}

Public resources for higher education are facing the same crunch as nearly every other sector of today's economy. Last year, 38 states faced budget deficits; policymakers throughout the nation are looking for ways to fill the gap. For example, state leaders have proposed tuition hikes as large as 60 percent over two years in the University of California system.

While the cost of attending many public institutions is rising, the maximum amount of federal student aid grants has not kept up. In fact, between the 1979-80 and 1987-88 school years, the average percentage of college-going costs covered by the maximum federal grant dropped from a high of 64.1 percent to 38.1 percent.

State grant and loan programs targeted by income haven't made up the difference. As a result, although most students are able to secure enough aid to pay for some sort of postsecondary program, the options available to low-income and, increasingly, middleincome students, are severely limited.

Policymakers are looking at ways to reform the higher education finance system while at the same time providing educational opportunity regardless of economic background. Many states, for example, are reviewing their policies of subsidizing the cost of higher education - both directly, in the form of grants and subsidized loans, and indirectly, in the form of tuition charges set at levels far below cost. Meanwhile, Congress is discussing a reauthorization of the Higher Education Act that would include a sharp increase in the ceiling on Pell grants and Stafford loans.
In order to broaden discussion about higher education finance, this policy brief outlines a proposal for a major change in federal financial aid, state tuition, and state financial aid policies. The proposal is drawn from a recently published book, Keeping College Affordable: Government and Educational Opportunity (The Brookings Institution, 1991), by Michael S. McPherson and Morton Owen Schapiro. 1

In the authors' view, "affordability" should be understood more broadly than keeping the financial contribution of students and their families as low as possible. Affordability should also take into account the budget constraints faced by the nation. One purpose therefore, of McPherson and Schapiro's research, is to help citizens and policymakers determine whether scarce resources are being invested as effectively as possible in higher education.

\section{A New Proposal for Government Support of Higher Education}

McPherson and Schapiro propose a way to enable fiscally strapped states to charge students and their parents a larger share of the actual cost of their college education. This, they predict, would lower state spending on higher education, without jeopardizing the educational opportunities of lower-income students and without putting an undue burden on middle- or upper-income students.

IMichael S. McPherson is the Herbert Lehman Professor of Economics at Williams College, Williamstown, Massachusetts. Morton Owen Schapiro is Professor and Chair in the Department of Economics at the University of Southern California. They are co-directors of the Williams Project on the Economics of Higher Education.

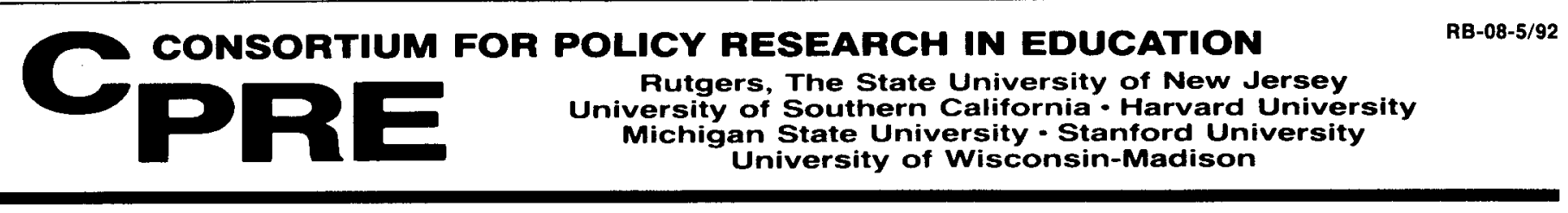




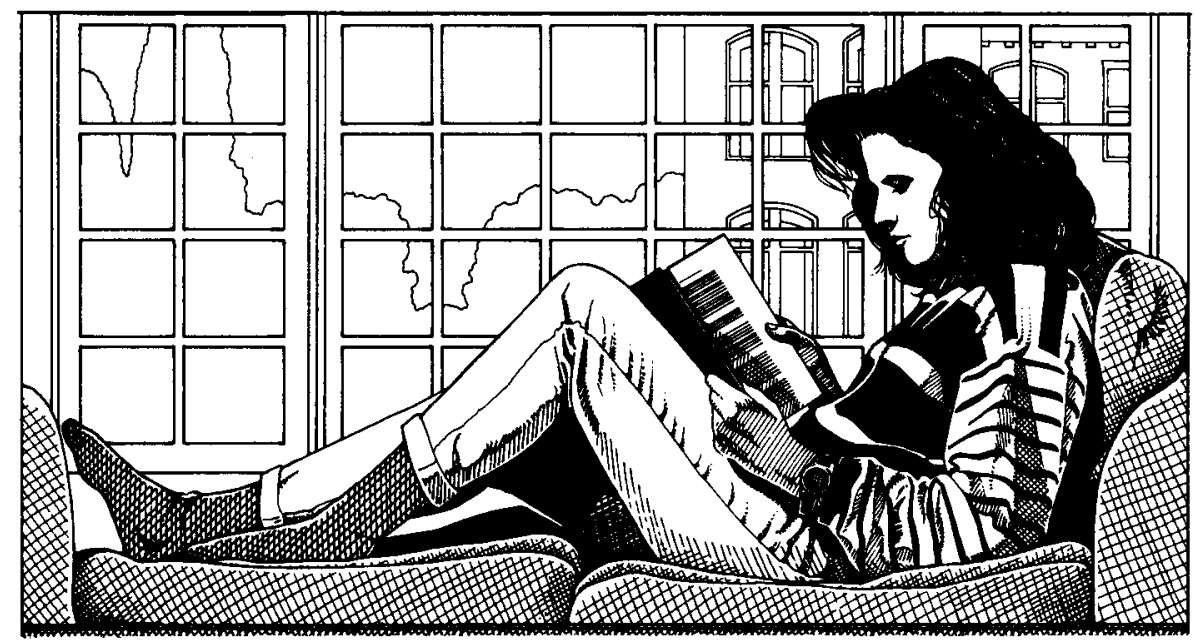

In 1985-86, the states spent about $\$ 30$ billion for higher education more than three and one-half times the amount spent for federal grants and loans to college students while charging students roughly one-quarter of those costs. The authors believe the societal interest in making higher education widely available can be served even if that percentage is raised somewhat.

The key element of the proposal is to greatly increase and simplify the federal aid programs targeted according to the ability of students or their family to pay. Such an increase by rough estimate would add about $\$ 11$ billion to the cost of federal student aid programs. The additional federal spending, however, could be offset at a rate of nearly 2 to 1 by higher state tuition revenues and, potentially, could reduce the total taxpayer-borne cost of higher education by about $\$ 12$ billion.

In addition to achieving salutary financial effects, the proposal's aims include:

- Targeting subsidies more effectively for lower-income students.

- Making high-quality educational opportunities available to more lower-income students.

- Reducing the state-to-state inequities in terms of access and affordability for less-advantaged students.
- Simplifying the federal student aid system.

In a word, the proposal is to federalize a greater share of the financing of higher education for lowerincome students. This would be achieved by setting the maximum federal aid grant for undergraduate students at a level approximating the actual annual cost of a year's education at a typical, public two-year college. This is the full amount spent to provide that education, not the partial amount charged to students. Residence costs would be included and a student contribution subtracted.

In 1985-86, the educational and general expenditures at public twoyear colleges averaged $\$ 4,223$ and room and board averaged $\$ 2,479$. Adjusting for inflation between 1985-86 and 1989-90 would bring the total cost to about $\$ 7,800$. The contribution required of the lowest-income students could be set at a modest $\$ 2,000$ annually, to be raised from summer work, parttime work during school and loans. The resulting $\$ 5,800$ grant ceiling is more than double the current maximum of $\$ 2,400$ and also is considerably higher than what is being debated in the reauthorization of the Higher Education Act.

Grant awards would be limited to the net cost to the students of the institutions they are attending and pegged to family income, declining to zero for a typical family with one child in college and an income of
$\$ 45,000$. That is close to the median U.S. income for families whose head is between 45 and 64 years old - the group most likely to have children in college. That also is roughly the income level at which the typical family is expected to contribute $\$ 5,800$ using current federal methodology. Using an income standard, it should be noted, is different from the "need" standard now employed. The effect would be that higher-income families, even if they had multiple students attending high-priced private colleges, would not be eligible for the greatly increased grants under the proposal.

The new program would, in effect, be a dramatic expansion of the Pell grant program. This expanded program would allow existing campus-based direct-loan programs, supplementary educational opportunity grants and work study to be eliminated.

Accompanying this substantial increase in the maximum federal grant would be a reform of federal loan programs for higher education. Federal loans would still be guaranteed - a necessary incentive to get private lenders to participate - but the interest charged would no longer be subsidized. The costs of anticipated defaults would be built into a loan-initiation fee and the money that had gone to subsidizing the loans would be shifted over to the grant program. As a result, students would have to borrow less and their repayment costs would be virtually the same as under the current program. The reasoning is that a subsidized loan is, in fact, a package consisting of a grant and a smaller, unsubsidized loan. Combining the two elements in a single package makes it more difficult to properly target either the subsidies or the gurantee that makes the credit available for students. McPherson and Schapiro believe that grants ought to be made to those who need subsidies, loans to those who need credit and some of each to those who need both. 
These changes in federal policy would provide states with a powerful incentive to raise tuitions to cover a much more substantial percentage of their costs, but without the fear of squeezing out lowerincome students. States that did not do so would be foregoing substantial federal revenues. To the extent that states did raise tuitions, the proposal would shift to the federal government a greater share of the burden of paying for the postsecondary education of lowerincome students.

\section{The Rationale for the Proposal}

Why transfer these costs from the states to the federal treasury? $\mathrm{McPherson}$ and Schapiro argue that fairness, ensuring equal opportunity and human capital development are national concerns whose costs ought, appropriately, to be paid for by the federal government. More specifically, however, they believe the proposed changes would improve the performance of all segments of higher education.

Many economists over the years have complained that the lowtuition policies of most states have some significant disadvantages. Not only are such subsidies poorly targeted toward the most needy, they also tend to insulate institutions from competitive pressures. In other words, because tuitions are deeply discounted, students usually are loath to complain about low quality. If students do complain, the disparity between cost and price can be used as an argument to undermine the complaints' validity. Further, regardless of quality, private institutions are placed at a decided disadvantage because of their higher tuitions.

The argument that public institutions are insulated from competitive pressures is probably most persuasive on campuses that mostly serve lower-income students. The existing financing system typically gives these students little choice about where to enroll, particularly because they may be financially compelled to live at home.

With a captive clientele, institutions are unmotivated to ensure that what they offer is of the highest quality given the available resources.

\section{How Would the New System Work?}

In response to a large increase in the maximum federal student aid grant most states would likely raise their tuitions substantially, to capture additional federal revenues. When the existing grant program began in the early 1970 s, some states did exactly that. McPherson and Schapiro's research suggests that every dollar increase in federal financial aid would lead to a 50cent increase in tuition at public four-year universities and colleges. If states went further, and raised tuitions dollar-for-dollar, state revenues would actually substantially exceed the amount of the added federal spending. That is because the higher tuition would be paid by far more students than would receive the federal aid.

Some states might wish to devote some of these new resources to helping more affluent students -

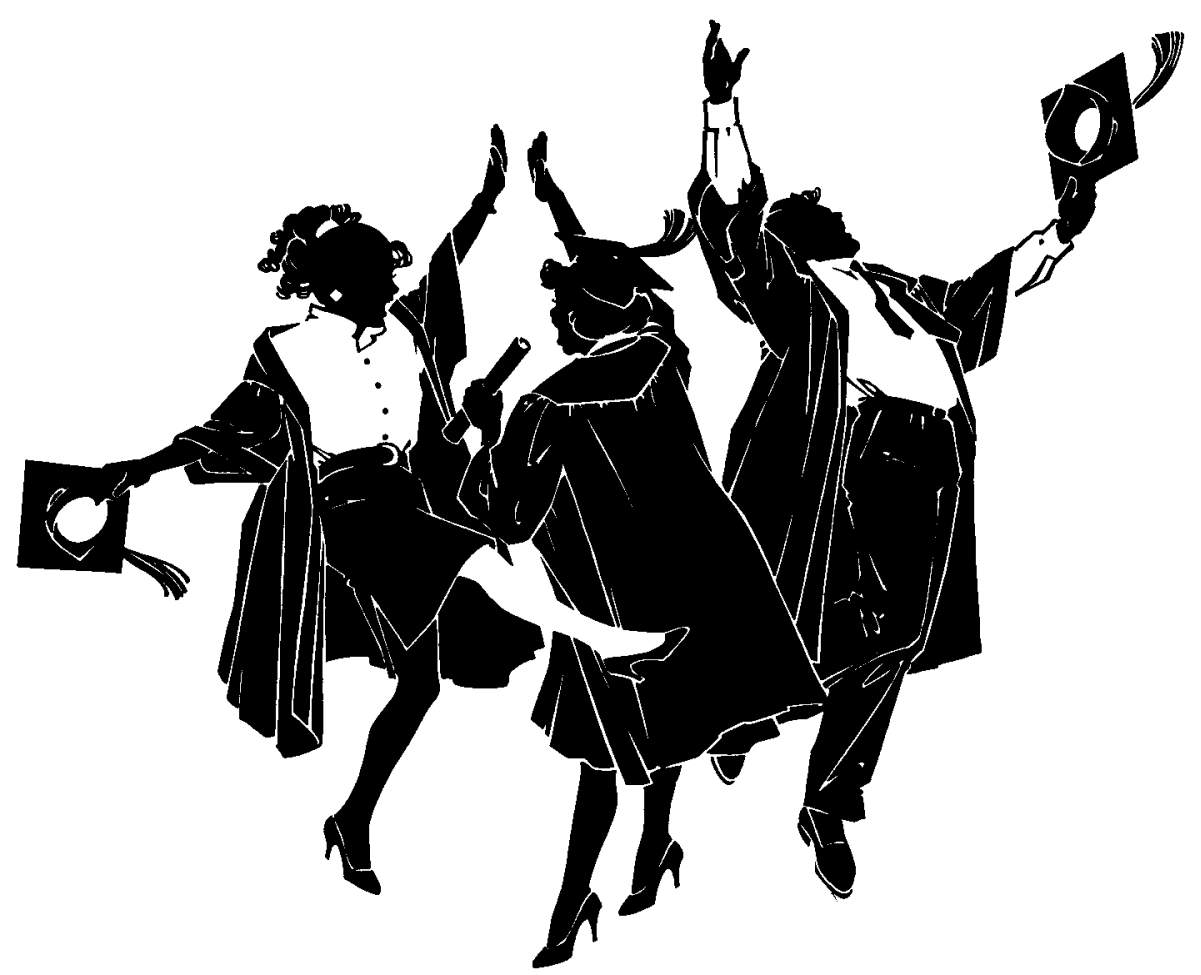
them ineligible for the higher subsidies - cope with higher tuition. If, for example, states developed or expanded need-based aid programs for state residents, the new, middle- and upper-income families eligible for some assistance.

Such a policy would, of course, reduce the redistributive effects of the proposed reforms. But, at least, states pursuing such a policy would have to do so openly, subject to public debate. Currently, some students are generously subsidized by low-tuition policies and that situation, in some states, has come to be seen as a virtual birthright rather than a resource transfer disproportionately benefiting the affluent.

Even if states did not pursue such a policy, middle- and upper-income students are unlikely to forego college because of its cost, say McPherson and Schapiro. Lowerincome students, however, do choose other life paths if they believe the cost of college to be too high. Thus, reducing the cost of postsecondary education for lower-income students would help achieve educational equity goals without raising an insurmountable financial barrier for more affluent students. those whose family income makes higher tuitions might make even 


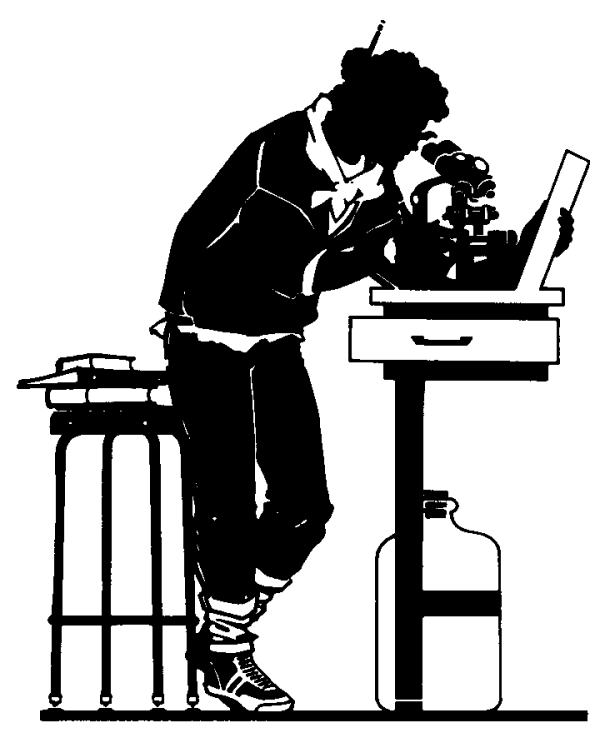

Opening the Doors to Private Colleges

How would the proposed reform affect private institutions? Lowerincome students are enrolled disproportionately in public institutions. Although most private college students receive some form of financial aid, rarely are institutions able to cover all of their costs. As a result, they choose to enroll elsewhere. The higher federal student aid grant would help close that gap - by reducing the required institutional contribution - and would in so doing offer lowerincome students more choices.

The increased federal aid would result in more public money going to private institutions and some might question whether that is justified. Two considerations argue that it is. First, most of the additional money going to private institutions would result from an increase in enrollments of lowerincome students: this would be an intended, positive outcome of the program. Second, there is no reason to think that the education lower-income students would receive at private institutions is of any less societal value than that provided at public institutions. Moreover, in states such as California, which are finding it hard to accommodate the students who want to attend public four-year

4 institutions, enabling more stu- dents to attend private colleges provides an economical alternative to adding costly capacity into the public system.

Most private colleges and universities currently charge more than the maximum grant proposed and would have no incentive to increase their prices. The relative handful of institutions now charging less than $\$ 7,800$ including residence costs could profitably raise their prices, but that may not be bad. Higher tuition, if it resulted in higher spending at such institutions, might well bring commensurate improvements in quality.

Because the proposal would target grants according to income, rather than need, the high grant ceiling proposed would not enable private institutions to unilaterally raise tuitions without suffering market consequences. If the current needs standard were retained, however, even relatively high-income families with multiple students enrolled in high-cost institutions could be deemed eligible for benefits. In that case, the new benefit levels could lead to unwarranted, and unwise, tuition and spending hikes.

\section{Non-Traditional Students and Institutions}

Using existing eligibility criteria, a large portion of the proposed higher aid grants would go to nontraditional students: independent adults; part-timers; students enrolled in non-degree programs in community colleges and attending proprietary vocational trade schools. It is not clear that, when distributed this way, the higher benefit amounts would contribute to achieving the goals of greater equity or efficiency.

A technical matter is that needsanalysis is less accurate in measuring the ability of independent adults to pay for college than it is in measuring families' financial strength. A larger issue is that all postsecondary education activities may not be of equal value to society. Continuing education, or even much of vocational training, may not always be worthy of federal subsidies.

The second issue is of greater concern, according to McPherson and Schapiro. They believe that most public institutions would, and should, raise their tuition charges in response to an increase in student aid grants. They also believe that most private colleges and universities already charge more than the proposed maximum grant and would not be inclined to raise their fees. It appears, however, that a large percentage of proprietary institutions charge roughly the same as the current maximum sum of Pell grants and Stafford loans - about $\$ 5,000$ annually per student. If that maximum were to increase, those institutions would likely raise their fees as well, although they may not use the additional revenues to increase program quality.

These concerns about equity, efficiency and resource utilization exist regarding vocational education even under the current student aid structure. But they are often obscured because federal student aid programs are now more indirect and complex than they would be after the proposed reforms. Bringing such subsidies into the open would be a catalyst for discussing the value of such expenditures to society.

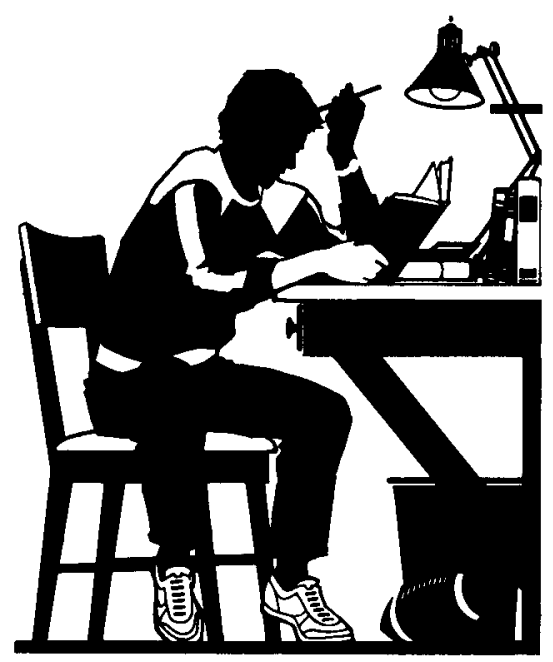


The point to remember is that if this proposal makes sense for financing traditional college students at academic institutions, the existence of other groups of students and other kinds of institutions that receive support from the public should not be an insurmountable obstacle to reform. If society determines that adult and vocational education ought to be supported by student grants, then so be it. But there may be alternative ways to support these other educational opportunities that may be more economical.

For example, aid to support nondegree programs or short-term vocational training could be administered separately from aid for academic programs that lead to degrees. Such programs might, as an example, be supported through contracts with providers. Students eligible to attend programs supported in this manner would be selected jointly by the provider and the funding agency. Students would not pay tuition and their living expenses might be funded directly. This arrangement would allow the government to impose performance standards, to supply training appropriate for the regional labor market and to more tightly regulate educational costs.

Such an arrangement would, in itself, represent a significant change in how adult and independent students receiving student aid for vocational or other nondegree programs are treated. But

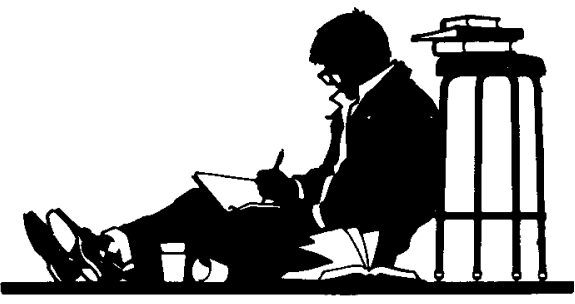

the way such students' needs are addressed, even if they attend academic programs, ought to be carefully structured if the size of the maximum grant is increased.

A needs analysis system should be developed that will avoid creating an incentive for students to move from dependent to independent status; independent students ought to be required to contribute more for their education than is required of dependent students; and, finally, the system should assess an independent student's ability to pay not on his or her resources while in school but, rather, on the resources available for several years prior to enrolling.

\section{Budgetary and Enroliment Implications}

The proposed plan's cost and effect on enrollment would depend on the reaction of students and college administrators to the changes. Consider the cost, for example, if all institutions, public and private, raised their tuitions enough to be able to collect the maximum feder- al grant amounts on behalf of their students. The cost to the government of increasing the size of grants for private college students now receiving a Pell grant or Stafford loan would be about $\$ 1$ billion. The cost of serving private college students who would be newly eligible - as a result of the higher grant ceiling - would be about $\$ 1.1$ billion.

The additional costs of the higher grants for students currently enrolled at publicly funded campuses would be about $\$ 3.4$ billion again assuming that all colleges raised their prices enough to collect the maximum amount from the program. Students who would be newly eligible for assistance because their colleges raised the tuition they charge - would add as much as $\$ 8.8$ billion annually to the cost of the program.

The combined added cost of the new, higher federal subsidies for lower-income students in public and private colleges could come to $\$ 14.3$ billion.

The cost of other federal student aid programs would fall or be eliminated altogether, partly offsetting the additional expenses. The three campus-based aid programs to be eliminated would save $\$ 1.2$ billion. Eliminating the interest subsidies for Stafford loans also would generate substantial savings of between $\$ 1.4$ billion and $\$ 2.3$ billion. The total net increase in costs for the higher grant programs

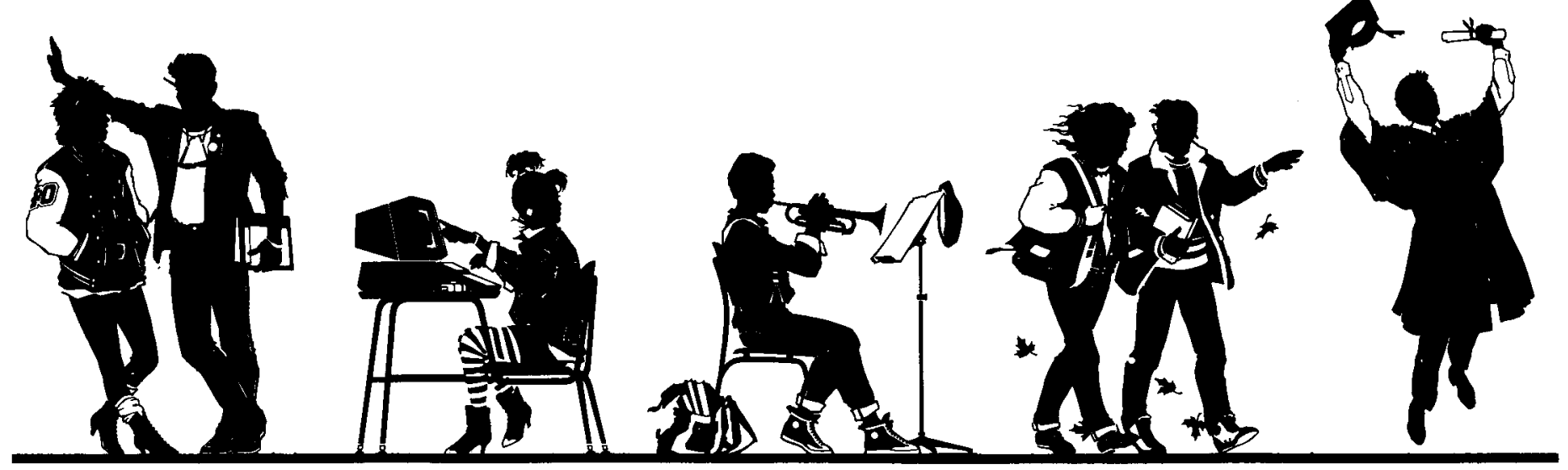


and the remaining loan program would be about $\$ 11$ billion.

McPherson and Schapiro's theory is that the new, higher tuitions that public colleges and universities could charge as a result of the greatly increased Pell grant awards would generate substantial revenues. To illustrate: in 1987-88, the average cost (including room and board) of attending a public college or university was $\$ 3,960$; if that average were to rise to $\$ 7,800$, the increase in state revenue would be about $\$ 23.2$ billion. Thus, unless states used part of the increased tuition for local student aid programs or program improvements, the net effect of the proposed policy would be to reduce total state and federal government spending on undergraduate education by about $\$ 12$ billion.

\section{Conclusion}

Although no one can be sure of the future, the ability of the states to continue financing high-quality postsecondary education while keeping tuitions low for all students is likely to be sorely tested in the years ahead. Without real changes in the financing system, lower-income students' educational opportunities are likely to continue to evaporate.

The reform proposed envisions a substantial increase in federal spending on student aid, offset by reductions in state spending. This runs counter to what has happened in recent years, when the federal government has pushed more and more fiscal burdens onto the states. Now, although the federal budget is still badly out of balance, states are reaching their capacity to tax their citizens to pay for services. That is why, during the 1990 s, proposals such as this might be welcomed.

Moreover, some of the more pressing issues we face $-\mathrm{K}-12$ education, prisons, health care - are clearly state and local responsibilities. Higher education, and in particular making higher education available regardless of a student's income, seems appropriately subsidized by the federal government. That is why increasing federal spending for higher education, as part of a broad package of reforms, may well be in order. Further pressure in this direction might arise from a renewed interest in state tax cuts or from proposals to reduce the deductibility of state income taxes on federal returns - which make it more difficult for states to raise revenues.

A reform proposal such as this would have to be implemented gradually. And it would likely have to be part of a more far-reaching reexamination of which level of government pays for what services.

Still, whatever hurdles to implementation, McPherson and Schapiro believe that their proposal, or else something equally comprehensive, is required to enable student aid programs to achieve their goals of equity and accessibility.

Need-based student aid, and in particular the federal Pell grant program, encourages lower-income students to go to college, makes their education expenses fairer in comparison to students who are not poor, and should not lead to price hikes on private campuses that would negate increases in the grants. Therefore, urge McPherson and Schapiro, needbased aid should be expanded as the key element of reforming higher education finance.

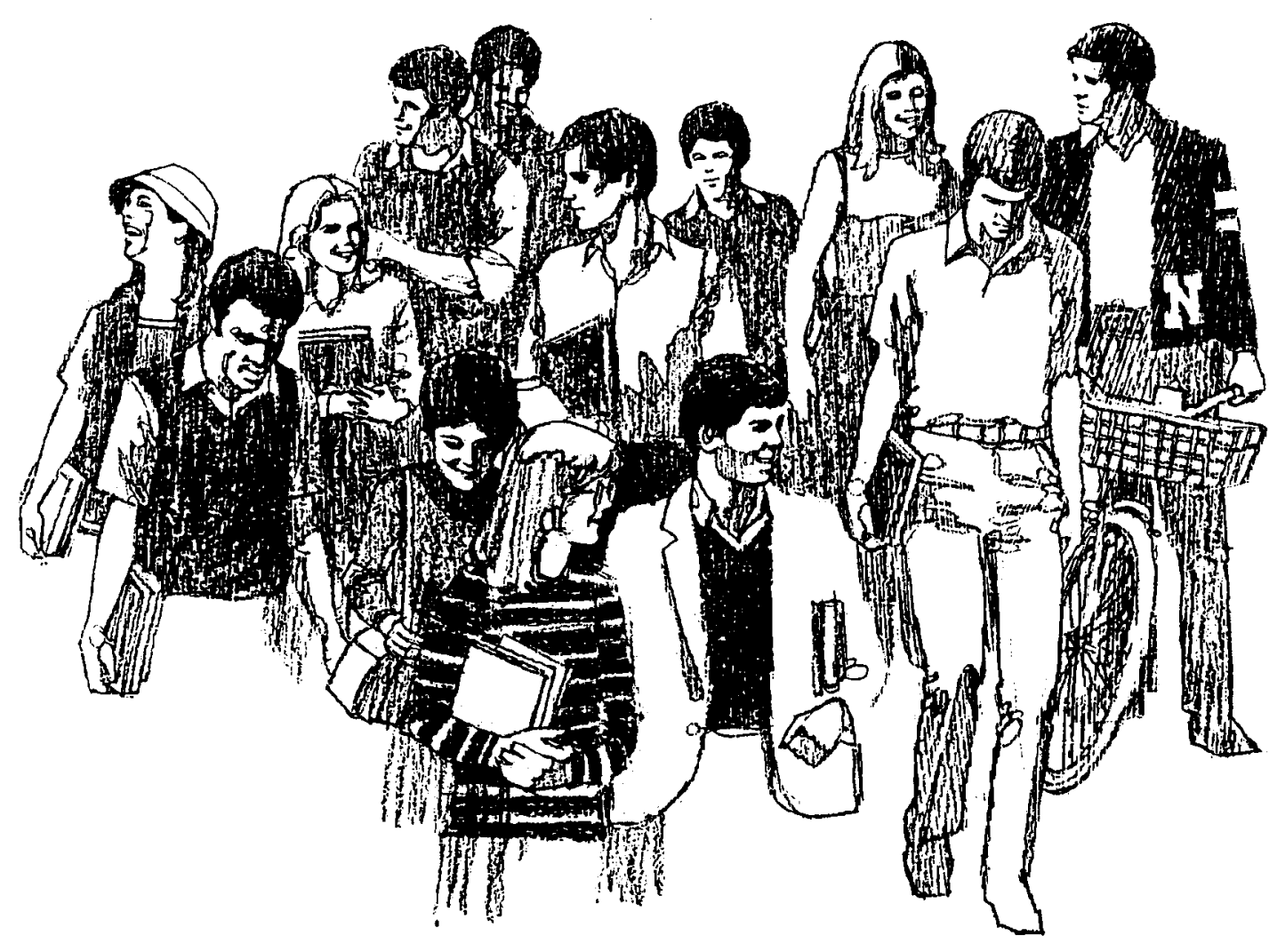

